\title{
TOTAL QUALITY AT PALESTINIAN UNIVERSITIES: THEORY AND PRACTICE
}

\section{Mahmoud A Abu Samra}

affiliated with Al- Quds University, College of Educational Science, Jerusalem, Palestine. E-mail: m_abusamra@yahoo.com

\section{Abstract:}

Purpose: The main objective of this paper is to explore the extent to which Total Quality Management (TQM) in Palestinian universities is available and utilized.

Design/methodology/approach: The paper reviews the literature and the research done in the field of TQM, and presents criteria from TQM for use in Palestinian universities. Higher educational institutions worldwide are committed to considering TQM doctrine as a philosophy, management attitude, and work approach. As Palestinian universities recognize the direction of this concept and its scientific, educational, and economic benefits and returns, they can compete in this field in the same way as economic institutions compete. Through the utilization of TQM methods, Palestinian universities can become exceptional and distinguished in having vision and confidence, accomplishing high quality performance and results.

Findings: The review of literature and research revealed that the criteria of TQM in Palestinian Universities is not freely available, and therefore is under-utilized. This study opens the door for more research in this important area.

Originality/value: This paper explores new directions in TQM research for Palestinian universities, which has not been intensively handled in the extant literature.

Keywords: Total Quality, Total Quality Management, Palestinian universities, staffing..

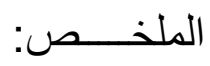

حرصت العديب من مؤسسات التعليم العالي الى تبني مفاهيم الجودة الثاملة، كفلسفة للتعليم العالي، وتوجه اداري، وتتافست في هذا الدجال كتنافس الدؤسسات الاقتصادية، لإدراكها دلات هذا المفهوم، ومردوده العلمي والتربوي والاقتصادي والعسكري وغبرها.

فالجودة الثاملة تعني التصيز، التميز في الطموح، والتميز في الرؤى والتنبؤ، والتمبز في الأداء، والتصبز في النتائج. هذا التصبز راود أذهان الأفراد والمؤسسات والمجتمعات و الدول، كان قديماً، وسبقى ما دامت المجتمعات البشرية، ورغب الجميع في الوصول الىى هذا التمبز. فمنهم من تحققت أهدافه، وبلغ شاناً بين أقرانه، ومنهم من أخفق، فرضي بالقليل، ومن هؤلاء من دافع عن هذا القليل واعتبره هو التمبز، وقليل هم الذين اعترفوا بأنهم لم يكونوا على قدر المسؤولية، وكانوا سبباً في عدم تمبز مؤسساتهم أو مجتمعاتهم فلم يحققو لكا جودة شاملة. وجامعاتنا الفلسطينبة لببت بهنأى عن هذا كله، فأبن هي من الجودة الثاملة؟ فهل سعت فعلًً لتحقيق الجودة الثاملة في رحابها ولخريجيها؟ أم ان أفكار الجودة الثاملة غبر قابلة للتطبيق في جامعاتنا؟ هذا ما تجيب عنه هذه الدراسة بثسء من التفصبل.

\section{INTRODUCTION}

Higher education serves a life message in a society and is responsible for its prosperity in all areas such as economic, social, intellectual, technological and political. The world around us is changing greatly and rapidly in the field of knowledge and in all other fields. Higher education is expected to be the solution to coping with these changes by preparing qualified graduates to take a leading role in the future as change agents, as well as to prepare intellectual and 
instructional leaders who are creative and can employ available resources in the most effective way. In addition, higher education is expected to take the pioneering role in determining a society's needs and continuing the search for creative solutions to those problems.

During the last two decades of the last century, higher education has been through major developments and changes, some of which created major challenges that affected higher education and its graduates. Globalization phenomena and the recent spread of information systems, telecommunications, satellites and the Internet have increased investments in the education industry, hoping to achieve the highest return. There are remarkable and increasing demands on higher education as well as other challenges that must be dealt with positively. Since higher education is a continual process based on the previous educational stages, it represents a critical era in developing the student's character and his/her intellectual maturity and achieving academic goals for society. Naji (1998) summarized the general purposes for the university as the following:

1. Advancing scientific research and encouraging performing its experiments on and off campus.

2. Contributing in changing and developing the local community's direction to the better and coping with the changes taking place in all scientific fields.

3. Contributing to fulfilling society's needs in terms of qualified and trained leaders by educating them in their areas of expertise.

4. Providing solutions for the local community around the university.

It is a fact that higher education cannot achieve its goals in economic and social development if conditions are unstable, its curriculum and graduates are unable to respond to the needs of the local industries, and the goals of the higher educational institutions are not well articulated. In all that has been discussed so far, the need is obvious for attention to the quality of higher education in all its elements, and this quality becomes a top priority for those administrations that are searching for excellence and wishing to enter the market of professional competition. Quality is well recognized in the process of educational improvement since it is one of the main cornerstones of Total Quality Management (TQM). This approach was founded to cope with global changes. The international community considers quality and educational reform as two faces of the same coin (Ahmad, 2003).

The discipline of TQM includes many of the management concepts, and it is consistent to a great extent with objectivity values. It aims to please both the learner and society, and to build bridges of trust and openness, teamwork and continuous 
improvements, and emphasizes incentives to encourage increased productivity, participation and sharing. It also depends on continuously measuring performance based on standards and predetermined criteria during the stages of production, or providing a service and taking the corrective measures to prevent the accumulation of digressions (Kanji \& Asher, 1996). The implementation of TQM in the educational field started in the eighties of the last century in the state of Alaska in the United States of America, where total quality management, known as continuous improvement, included the restructuring of the relationship between teacher and student from one of teacher and learner to that of working in the spirit of one team.

On the level of the Palestinian educational environment, Kamal (2002) indicated that the education sector in general and higher education in particular needed to re-examine its objectives, programs and administrative and organizational structures, in order to develop its duties and functions, its services and its outputs, and to reach a high level of quality, harmonizing needs and developments to promote community on the path to improvement. The introduction of this relatively recent approach is justified, and calls for more attention on the part of educators, because there is much evidence that we need to shift toward the philosophy of TQM for the potential gain of satisfactory, sustainable solutions able to develop and reform the educational system. The increasing demand since the beginning of the last century that has led in most societies to the expansion of education has also sometimes led to sacrificing the quality of education, which has contributed to increasing unemployment rates (Ahmad, 2003). The need for better use of scarce resources for development compels educational institutions to respond to the demands of comprehensive quality.

\section{Total Quality and Total Quality Management}

The concept of quality forms the basis for the introduction to total quality management, and like other terms, 'quality' is considered one of the concepts that vary according to the views of researchers and thinkers from diverse tendencies and different backgrounds. However, these differences do not extend to the essence of the concept, as the substance, 'pursuit of customer satisfaction,' was in the economic area from the beginning. Hence, this term is derived from the business sector, and most of those who have tried to define it are economists. Besterfield (1994) views quality as a technique to ensure the survival and continued competitive advantage of the institution. Aquili (2001) sees quality as the production of goods or services with a high level of efficiency, and creating a distinction wherein to meet the needs and expectations of the customer.

There has been increased interest in 
the subject of quality brought about the development of so-called Total Quality Management (TQM), which has proved successful because it contains principles and ideas that express care about the humanitarian aspect, in addition to the emphasis on the distinction of services or products. TQM, according to Dobyns and Crawford-Mason (1997), is a method of administrative practice that requires a major shift in the entire institution's management and values in order to reach continuous improvement of the product to ensure client satisfaction within and outside the educational institution. Oshiba (2000) defined TQM in the educational institution as a set of activities and practices carried out by those responsible for the running of the institution, which includes planning, implementation, quality evaluation and improvement in all areas of the educational process at the university. He also pointed out that the philosophy of comprehensive quality as a scientific approach to management started in the early forties of the last century, due to a group of American intellectuals headed by Edward Deming, Joseph Juran and Philip Crosby, who were behind the use of statistical methods in the examination and testing of quality through statistical control applications.

It could be argued that the concept of TQM has undergone several stages through the historical evolution of quality and control. Over the successive stages of these concepts they developed into the modern concept of total quality management. These phases of development were Inspection and Test, Quality Control, Quality Assurance, and Total Quality Management (TQM), which emerged as a concept after 1980 . This final stage depends on a comprehensive concept of the quality of performance of the organization as a single unit. This comprehensive quality uses sophisticated methods in dealing with consumers, paying increased attention to the customer to achieve greater success for the institution. TQM consists of the overall strategic framework for activating quality management systems and keeping quality systems, in addition to the management of administrative processes and outputs of the functional relationship, which affect the external environment in all of its components. This phase is focused on the importance of the customers and meeting their needs, as they are the final recipients of the goods or service education, which governs the quality. The institution must adopt the values and principles of sound management capable of closely managing the educational process, and give greater importance to employees at the company to raise their morale (Davis and Burnham, 1997). It was noted during the historical development and emergence of the ideas of TQM, that this method was neither created at one point in time, nor through a surge in administrative thought, but came about through a series of developments in 
management thinking, and the emergence of some shortcomings in many schools of administration.

The practice of TQM and its administration is as old as the practice of management itself, but the new development is its emerging with that name as a science that is a subject for research with its own theories. The most important pioneers of TQM are (Vileeh, 2003; Doherty, 1999)

- Edwards Deming, who focused on the main ideas of the fourteen 'Quality Management Points' and 'The Deadly Diseases.'

- Joseph Juran, who translated his ideas through 'The Juran Trilogy' for quality management that included quality planning, quality control, and quality improvement. Philip Crosby, who focused on output through defects in performance; he first called for the concept of zero defects.

- Kauro Ishikawa, called the real parent of workshops for quality, was the first to advocate the formation of small groups of workers joining voluntary quality seminars, to find out about the problems they face and to propose solutions to develop and improve performance, taking into account the human dimension of the work and highlighting the diligence of the leaders.

There has been some confusion between the concept of TQM and the International Organization for
Standardization (ISO) 9000 system, and ISO 9000 has been spoken about as if it was TQM. To illustrate the difference between the two concepts, it can be said that ISO 9000 is an approach to total quality management, as it represents the specifications for quality assurance. Many of the principles of the TQM system are included in the system's chain of ISO 9000. The relationship between the two is strong and overlapping in the form and structure of sound administrative tools used in scientific development, in order to achieve the objectives of comprehensive quality and continuous improvement in client satisfaction. Therefore, the application of ISO 9000 will not be effective unless its application is accompanied by the conviction and commitment of senior management, using professional techniques in all areas during the process of quality development. Accordingly, the ISO 9000 is not a comprehensive quality management philosophy, but contains many of the principles of TQM, as ISO 9000 includes specifications for quality assurance. This is not a substitute for the technical specifications of goods and services, but is complementary to it. In other words, there must be the production of the goods or services through a system of quality corresponding to the specifications as in TQM.

Total Quality in Higher Education 
The international standard of ISO 9000 achieved a greatly successful system, and has been espoused by several countries as their national standard. They have then extended the ISO 9000 standards from industry to the areas of education and training. Developing common standards in line with international standards to be applied to education is an important and serious matter, taking into account the specificity of inputs, processes and outputs of the educational process. However, school is not a factory, and the student is not a product.

The International Quality System (IQS) 9001 includes twenty elements as spelled out by Wouter, listed by Clery (1993), and these elements are translated into the education sector as follows in Table 1:

Table 1: Twenty IQS Elements of Education Sector.

\begin{tabular}{|c|c|c|}
\hline NO. & Elements of IQS 9001 & Translation into the Education Sector \\
\hline 1 & $\begin{array}{l}\text { Responsibility of the } \\
\text { administration }\end{array}$ & $\begin{array}{l}\text { Management responsibility with regard to training, the } \\
\text { clarification of authority and responsibility, clarifying the } \\
\text { policy of quality, objectives etc. }\end{array}$ \\
\hline 2 & Quality system & $\begin{array}{l}\text { Procedures are in place to ensure the quality of } \\
\text { educational services, the quality of financing, the } \\
\text { quality of teaching methods, etc. }\end{array}$ \\
\hline 3 & $\begin{array}{l}\text { Review of the } \\
\text { contract }\end{array}$ & $\begin{array}{l}\text { The procedures for meeting the needs of customers (the } \\
\text { student, the government or industry sector etc.), which } \\
\text { must meet the terms of the contract between the } \\
\text { educational institution and the customer. }\end{array}$ \\
\hline 4 & $\begin{array}{l}\text { Manuf } \\
\text { Monito }\end{array}$ & $\begin{array}{l}\text { The curriculum development and ensuring its } \\
\text { improvement. }\end{array}$ \\
\hline 5 & $\begin{array}{l}\text { Managing } \\
\text { documents } \\
\text { records }\end{array}$ & $\begin{array}{l}\text { Includes information systems, which are in line with } \\
\text { ongoing developments and changes. }\end{array}$ \\
\hline 6 & Purchasing & $\begin{array}{l}\text { The speed and quality required in what the educational } \\
\text { institution receives from suppliers. }\end{array}$ \\
\hline 7 & $\begin{array}{l}\text { Monitoring } \\
\text { materials }\end{array}$ & $\begin{array}{l}\text { Admission of students in accordance with the terms of } \\
\text { the educational institution. }\end{array}$ \\
\hline 8 & $\begin{array}{l}\text { Marking and tracking } \\
\text { products. }\end{array}$ & $\begin{array}{l}\text { The responsibility of tracking the status and progress of } \\
\text { the student and his or her achievement. }\end{array}$ \\
\hline 9 & Control operations & $\begin{array}{l}\text { Planning study programs, who is responsible for planning, } \\
\text { what is happening inside the room row, etc. }\end{array}$ \\
\hline 10 & Testing and exams & $\begin{array}{l}\text { Examination of the students enrolled in the } \\
\text { university to determine that their scientific } \\
\text { backgrounds are at the university level. }\end{array}$ \\
\hline 11 & $\begin{array}{l}\text { Organs of inspection, } \\
\text { measurement and testing }\end{array}$ & $\begin{array}{l}\text { Evaluation methods that are used in an institution of } \\
\text { higher education. }\end{array}$ \\
\hline 12 & $\begin{array}{ll}\text { Results of } & \text { the } \\
\text { examination or test }\end{array}$ & $\begin{array}{l}\text { Results of student evaluations and their validity, } \\
\text { reliability and objectivity. }\end{array}$ \\
\hline
\end{tabular}


Mahmoud A Abu Samra

\begin{tabular}{|c|l|l|}
\hline NO. & Elements of IQS 9001 & Translation into the Education Sector \\
\hline 13 & $\begin{array}{l}\text { Checking for defective } \\
\text { products }\end{array}$ & Remedial actions in the case of student failures. \\
\hline 14 & Corrective actions & $\begin{array}{l}\text { The reasons for the failures in order to take } \\
\text { preventive action, and the procedures in place to } \\
\text { avoid future student failures. }\end{array}$ \\
\hline 15 & $\begin{array}{l}\text { Delivery, storage, } \\
\text { packing, shipping }\end{array}$ & $\begin{array}{l}\text { University atmosphere, communications, health, } \\
\text { security of the students and staff, buildings, } \\
\text { ventilation, etc. }\end{array}$ \\
\hline 16 & Quality records & $\begin{array}{l}\text { Records of the educational learning process, their } \\
\text { accuracy, accessibility, properly amassed and indexed } \\
\text { etc. }\end{array}$ \\
\hline 17 & Quality internal audit & $\begin{array}{l}\text { Assuring curriculum safety, teaching and evaluation } \\
\text { methods, coping with changes and developments and } \\
\text { benefiting from the feedback. }\end{array}$ \\
\hline 18 & Training & $\begin{array}{l}\text { Includes programs developed for the training of } \\
\text { faculty members and administrators. }\end{array}$ \\
\hline 20 & Services & $\begin{array}{l}\text { Follow-up services to graduates in their places of work } \\
\text { to uncover their strengths and weaknesses. }\end{array}$ \\
\hline
\end{tabular}

Malcolm Baldridge, who served as

Minister of Trade during the Reagan administration in 1981, introduced the concept of total quality to education in the United States. Baldridge advocated the application of the concept of total quality until his death in 1987, through a set of five principles (El-Bilawi, et al., 2006):

1. Administrators and faculty members must all strive to achieve quality.

2. Focusing must be used to prevent student failure, rather than studying failure.

3. Using statistical controls accurately to improve management processes and revenue from the students.

4. Initial training in quality for the management is very important; every person in the enterprise must be trained for quality.

5. The need to agree annually on clear criteria that verify the quality of processes and outputs.

In the opinion of Doherty (1999) the goal of every educational institution is to provide students with opportunities to develop themselves in four areas:

- Knowledge, which enables understanding,

- How things work, which enables performance of tasks,

- Wisdom, which enables one to identify priorities,

- And character, which enables fruitful cooperation in the community.

An educational literature review (Ahmad, 2003; Jamel, 2002; Ahmad \& Hafiz, 2003; Alssunbul, 2002) shows that the overall quality 
of university education can be achieved through excellence in a variety of elements that can be identified as follows:

- Quality of faculty members: The selection of a qualified faculty member, capable of outstanding performance in teaching and research. One cannot give what one does not have, thus the importance of preparing him or her scientifically and educationally in the practical and theoretical aspects of an integrated and consistent framework. This contributes to the enrichment of the educational process, and allows constant monitoring of performance in teaching and research.

- Quality of students: The criteria used in terms of their acceptance and joining the university; the quality of their rehabilitation, mental health and psychology, ability to learn educational programs, and capability of building upon the wealth of knowledge that they accumulated before joining the university. Students currently play an important role in the success of the educational process through the opportunity to express their opinions on the curriculum, the efficiency of faculty members, and the effectiveness of teaching.

- Quality of educational programs: Educational programs are a reflection and interpretation of the educational philosophy and goals adopted by the institution according to its beliefs and ideology. Quality programs are characterized by depth, inclusiveness and integration, to achieve the goals and aspirations of the university.

- Quality of teaching methods: The teaching methods or techniques are chosen by the teacher to achieve the desired behavioral and educational goals. There is no ideal way of teaching, but effective teaching methods have certain criteria mentioned in educational literature.

- Quality of the buildings and equipment: In terms of its rooms, there must be enough space for the students, quality lighting and ventilation, and meeting general conditions for the safety of users, as well as the existence of good laboratories capable of meeting the obligations of teaching and scientific research.

- Quality of university funding: Since university education is costly, especially if it includes modern educational technology, universities must search for sources of funding to conduct their affairs in hand, while working to ration fiscal spending on the other hand. In other words, the quality of higher education is directly related to the quality of university funding.

- Quality of legislation and regulations of the university: These must be clear and specific, able to cope with change and take into account scientific and technological advancement.

- Quality of university performance 
evaluation: In order to judge the performance of the university and how it achieves the desired goals, there must be criteria for judging the quality of the educational process including the administration, teachers, students, programs, etc.

- Quality of the administration: This includes the quality of the administrative process exercised by each director or supervisor in the university system, and to what extent the university administration was able to achieve the goals set by the university itself.

Based on the literature related to the concepts of ' total quality management,' TQM, and total quality of education at the university in particular, we can draw the following conclusions:

First: The administrative processes of planning, organizing, supervising, financing and staffing, the criteria for selecting students, the quality of educational programs, and the quality of performance evaluation, can all be achieved only through university management (leadership) that understands the meaning of total quality, and believes in its application. The leadership can then guide the university according to the concepts and visions of TQM, seeking to reach the concept (zero defects) in each step of the higher education process. This would bring about high quality from each university production.
Teaching process: This can be seen through the student, who is able to play the role required from him or her after graduation. Scientific research: This can be evaluated through the support of the university toward applicable research, and the ability of faculty members to do quality research. Finally, Community service: This is the third function of the university's duties. In other words, the university administration is responsible first and foremost to achieve total quality at the university. In this context, Vileeh (2003, p. 340) says that "Joseph Juran considers that most of the problems of quality are caused by the administration, and the misuse of administration may cause $90 \%$ of these problems".

Second: Through observing the elements of the total quality of higher education, researchers have noted that in the main administrative process, all elements of the total quality of the university are built upon staffing. When this process is based on purely professional principles, and the criterion of efficiency, which is based on specialization and excellence, is the basis of staffing, this will automatically verify all the elements of total quality at the university. On the contrary, when staffing is based on nonprofessionals, without taking into account efficiency or specialization, then how can we achieve any of the elements of total quality? The quality of the staff, the selection and quality of the university students, the quality 
of the performance appraisal, the quality of university funding and spending, the quality of planning, the quality of legislation and regulations- all of these functions or operations are based on persons. If their selection or staffing is based on purely professional principles, then we can say that all the administrative processes are professional, and vice versa.

Third: When we say 'total quality,' we mean all its components together. If the verification element or any of these elements has not been achieved, we cannot say that we have arrived at total quality. There is no sense of distinctive buildings in the absence of distinguished faculty members, and there is no meaning to educational programs in the absence of standing students or lack of funding, or current equipment and technology. There is no meaning to a set of total quality components found in the university in the absence of effective management that strives to invest all the elements in order to preserve and upgrade the quality and lead the competition. There is no room to say that this university has a total quality of $90 \%$, or $95 \%$, but is limited to two options: either total quality, or lack thereof.

Fourth: Although many studies, whether Arab or foreign studies, have pointed out the need to adopt TQM in education in general, and in higher education in particular, yet it could be argued whether the need for educational institutions and others to apply the ideas and principles of quality management is necessary, if they wish for these institutions to make a difference. According to the concept 'quality,' any outstanding performance requires implementing total quality management for the individual or the group or institution. To do otherwise is to expect that these institutions and departments will not be able to compete, and may not even survive. Even if these institutions do survive for a period of time, yet they are a burden on society and a source of damage, hindering prosperity, through their lack of services or distorted output that has fallen below the level of excellence and perfection.

Palestinian Universities and Total Quality Management

Through attention to the concepts of total quality, and the reality of its elements and components in higher education, as well as noting the achievement objectives of TQM, and through observing the reality of the situation in most Arab universities in general and Palestinian universities in particular, it can be said that these universities are still far from having total quality and TQM. Even though we have seen one or more of the elements of total quality in some universities, such as the keen desire to find outstanding students, others having unique buildings and equipment, and a third of the regulations and laws keeping pace with the changes, the total quality we advocate is the quality of all the 
elements together, and this is not what we see in most of these universities. These results can be observed in two ways.

First: The results of some studies in this area have pointed out that Palestinian universities have not achieved the principles of TQM (Abu Samra, Alawneh, \& Abbasi, 2008; Abu Samra, Zidan, \& Abbasi, 2006; Geriace, 2004; and Khalaff, 2006). Those results showed that not all indicators of TQM in the Palestinian universities were up to the required level, from the point of view of both students and workers in these universities. Second: Scrutiny of the above-mentioned total quality components in universities can determine whether the management of these universities is 'Total Quality Management' or not. We will discuss these elements through a series of questions under specific subject headings:

\section{Quality of faculty members:}

a. Will the selection of all members of the teaching staff be based on purely professional criteria? (University, academic level, experience, adequate specialization, the ability to do teaching and scientific research efficiently).

b. Is the ongoing evaluation of the performance of all faculty members based on scientific principles?

c. Will they dispense with the services of a member of the teaching staff if he or she is unable to efficiently carry out functions of teaching and scientific research?

d. Is the policy to follow each member's performance in education and research, and note the amount of research published during a certain period of time? Is the policy to then dispense with his services if otherwise?

e. How many faculty members' services have been dispensed with according to the concept 'up or out policy,' or 'publish or perish'?

f. Is the role of faculty members purely academic or do they make other contributions of significant scientific value?

g. Can the university compete with prestigious universities worldwide based on the performance of the members of its teaching staff?

\section{Quality of students:}

a. Is the number of university students to be admitted determined in advance?

b. Based on what criteria are the students accepted at the university?

c. Is the guideline rate the sole criterion for admission?

d. Is there accurate evaluation of the academic performance of students during the years of study?

e. What constitutes success in specialized courses?

f. Does the university examine the rates of acceptance and performance levels of university students? 
g. Does the university monitor the behavior of its students inside the university campus?

3. Quality of teaching methods:

a. Are the faculty members using a variety of teaching methods?

b. Are the teaching methods:

i. Sensitive to the stages of development and the inclinations of the learners?

ii. Based on theories of education?

iii. Sensitive to the physical characteristics and mental growth of the students?

iv. Sensitive to the learners' hoped for educational goals?

v. Sensitive to the individual differences among students?

vi. Sensitive to the nature of the material and the academic topics?

4. Quality of buildings and equipment:

a. Are the halls' sizes commensurate with the number of students using them?

b. Are the teaching rooms equipped with heating and appropriately ventilated?

c. Are the offices of the faculty members comfortable?

d. Are references and scientific periodicals are available for students and faculty members?

e. Do scientific laboratories accommodate the purposes of scientific research?

\section{Quality of university funding:}

a. Does the university have stable funding sources?

b. Are these sources sufficient for the expenses of the university?

c. Is there enough diversity in university funding sources?

d. What is the annual deficit rate of the university's budget?

e. Does the university suffer from problems in current expenditures?

f. Does the university have investment projects?

g. Does the university depend on any external financing with conditions?

\section{Quality of legislation and regulations:}

a. Is the drafting of legislation and regulations done by specialists?

b. Will the legislation be reviewed from time to time?

c. Does the university take into account the specificity of the legislation and the regulations of Palestinian society?

d. Are the rules specific to achieving the university's educational goals?

e. Do the workers feel that much of the university's legislation and regulations are inapplicable?

7. Quality of the university performance appraisal:

a. Is there a quality unit or control for the university?

b. Does this quality unit shape the culture among university employees? 
c. Does the university follow standards for performance appraisals?

d. What are the foundations of the performance criteria?

e. Will the university deal seriously with the results of the performance appraisals?

f. Do they provide feedback to employees on the results of university performance appraisals?

g. Does the university provide incentives, positive or negative, based on the results of the performance appraisals?

\section{Quality of the university administration:}

a. Are the short-range and long-range objectives of the university administration clear and specific?

b. Does the university administration:

i. Evaluate these objectives, and is their description verifiable?

ii. Strengthen the competitive edge of the university between counterparts?

iii. Seem keen on the participation of workers in making and targeting the university's policies?

The answers to these questions determine the total quality of the university and administration, whether at home or abroad. There is no doubt that Palestinian universities are outside this domain, and no one can say that our universities look like universities in the United States of America or Japan. The contributions of all of the Arab world universities in the areas of scientific research and its results, patents, solutions to economic, environmental and military problems, and problems of food and medicine are negligible. We do not believe that the large numbers of graduates pumped out by Palestinian universities into the job market show evidence of quality or quality management. If this is the case with Arab Universities, we think that Palestinian universities will not be better. Where is their total quality in performance? And where is the TQM in Palestinian universities?

To this it can be said that TQM in Palestinian universities, as well as the overall quality of higher education, consists only of theoretical ideas; we did not see any true sense of the practical reality. Any attempts by Palestinian university administrations in this area have not carried over to our universities the level of the 'quality boom,' which is well known to have touched many distinguished universities in performance management, and touched local communities through production of the universities applied in all fields of work.

\section{CONCLUSION}

No one can deny the importance of total quality in every area of life, especially higher education, nor can one deny the basic burden on the university administration to achieve the educational goals entrusted to them. Many universities in the Western world, as well as the Israeli universities, play 
highly important roles in their communities, and they are the first line of defense for these communities in all areas of life through the research and inventions coming from them.

Total quality in universities is not an impossible goal, even though it may not be seen as a characteristic of certain individuals or communities. But its foundation in performance, labor and service, and its execution, is accessible, if there is the goodwill and potential required. The components are known, and it only remains to university administrations to strive sincerely to achieve total quality in our universities, and leave a crystal clear imprint in the field of university education. If the Arab Universities in general are in need of Total Quality Management, then the Palestinian universities are the most in need of it.

\section{REFERENCES}

1. Abu Samra, M. A., Zidan, A. H., and Abbasi, O. M. (2006), "The reality of the educational system at Al - Quds University in the light of total quality management standards from the viewpoint of the faculty members" Journal of the Association of Arab Universities, Vol. 45, pp. 165 -209.

2. Abu Samra, M. A., Alawneh, M. J., and Abbasi, O. M. (2008), "Indicators of total quality management at Al - Quds University from the point of view of students", Journal of Al - Quds Open University for Studies and Research, Vol. 12, pp. 11- 46.

3. Ahmad, I. (2003), Comprehensive quality in educational and school administration, World of Libraries, Cairo, Egypt.

4. Ahmad, H., \& Hafiz, M. (2003), The management of educational institutions. A World Library, Cairo, Egypt.

5. Alssunul, A. A. (2002), Education in the Arab world at the beginning of a new century, The Modern University Office, Cairo, Egypt.

6. Aquili, O. (2001), Integrated methodology for total quality management, The Point of View, Dar Wael for Printing and Publishing, Amman, Jordan.

7. Besterfield, H. (1994), Quality Control. $4^{\text {th }}$ ed., Prentice-Hall, Inc, NJ.

8. Clery, Roger G. (1993), ISO 9000 Quality Systems: Application to Higher Education. ERIC No. ED363136.

9. Davis, B. \& Burnham, J. (1997), Reengineering and Total Quality in Schools, Pitman, London.

10.Dobyns, L. and Crawford-Mason, C. (1997), Thinking About Quality: Progress, Wisdom and the Deming Philosophy, Interpretation by Hussein Abdul Wahid, the Egyptian Societyfor the Dissemination of Knowledge and Global Culture, Cairo, Egypt.

11.Doherty, G. (1999), Developing Quality Systems in Education, Translated by Adnan Al Ahmad, Arabic Organization for Translation, Culture and Science, Damascus, Syria. 
12.El -Bilawi, H. H., Toama, R., Sulieman, S., Nageeb, A., Saed, M., Bandari, M., and Abd- Elbagee, M. (2006), Total Quality at Education. Dar Al Massera for publication, distribution and printing: Amman, Jordan.

13.Geriace, E. (2004), "Total Quality Management and Its Applications at the University of Bir Zeit", Unpublished MA, Al - Quds University, Jerusalem, Israel.

14.Jamel, A. R. (2002), Teaching Methods and Skills of the Implementation and Planning of the Teaching Process. Dar Curricula for Publishing and Distribution: Amman, Jordan.

15.Kamal, S. (2002), "Ensuring Quality in Open Learning and Distance Learning", Journal of Al - Quds Open University Research and Studies, Vol. 1, pp. 28-50.
16.Kanji, G. and Asher, M. (1996), 100 Methods for Total Quality Management, SAGE Publications Ltd, London.

17.Khalaff, R. (2006), "Difficulties of applying total quality management principles at the Universities of Hebron and Bethlehem from the viewpoint of members of the teaching staff and students", Unpublished MA, Al - Quds University, Jerusalem, Israel.

18.Naji, F. (1998), "Total Quality Management and Its Applications in Higher Education Institutions", Unpublished MA, Yarmouk University, Jordan.

19.Vileeh, F. A. (2003), Economics of education, Dar Al Massera for publication, distribution and printing, Amman, Jordon. 